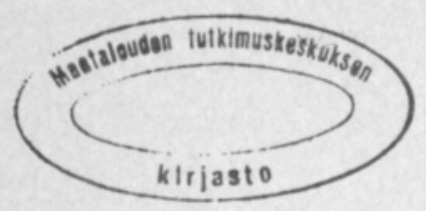

\title{
Nitrogen and potassium fertilization of potato
}

\author{
Hilkka TÄHTINEN \\ Agricultural Research Centre, Department of Agricultural Chemistry and Physics, \\ SF-01300 Vantaa 30, Finland
}

\begin{abstract}
Fourteen one-year N- and K-fertilization experiments for potato were carried out on coarse mineral soils on different sites in Finland. The nitrogen fertilization (from 50 to $156 \mathrm{~kg} / \mathrm{ha} \mathrm{N}$ ) was given in the form of ammonium nitrate limestone, and the potassium $(42-179 \mathrm{~kg} / \mathrm{ha} \mathrm{K})$ in potassium sulphate.

The nitrogen fertilization affected significantly both the yield and the quality of the tubers. The maximum tuber yield was achieved at the nitrogen application rate of 110 $\mathrm{kg} / \mathrm{ha}$. The economically most advantageous fertilization rate was $80 \mathrm{~kg}$ of nitrogen per hectare, if only the amount of the yield was taken into account. The nitrogen fertilization weakened the quality of the tubers. The weight and the size of the tubers increased, but the starch content of the tubers decreased as a result of the nitrogen fertilization. The starch yield also turned out to be the smallest at the heaviest nitrogen fertilization. Further, the biggest rate of nitrogen weakened the flavor of the tubers, depressed their mealiness, and increased slightly their discoloration when raw. The fertilization had no effect on the darkening of cooked potatoes.

In these one-year experiments, the increase of the potassium fertilization from 42 $\mathrm{kg} / \mathrm{ha} \mathrm{K}$ did not have a significant effect on the yield and the quality of the tubers.
\end{abstract}

\section{Introduction}

Attention has recently been directed in Finland to the fertilization of potato with the view of not only achieving the optimum economical result, but also of being able to produce potatoes of good quality (VARIS 1970, 1972 a-d, 1974, Ellala et al. 1971, Jokinen 1977).

For potato fertilizing one uses in Finland principally a compound fertilizer in which the ratios of the amounts $(\%)$ of $\mathrm{N}, \mathrm{P}$ and $\mathrm{K}$ have been 7,11 and 12 , respectively. In practice this fertilizer is seldom supplemented with singlenutrient fertilizers. Using the following data from field trials an attempt will be made to investigate the effect of the application rates of nitrogen and potassium fertilizers on the yield and the quality of the tubers.

\section{Material and methods}

The investigation consists of 14 field trials with potato, carried out in the years $1969-1971$. The treatments entailed the various combinations of three 
rates of nitrogen $(\mathrm{N})$ and of three rates of potassium (K) with the following retes:

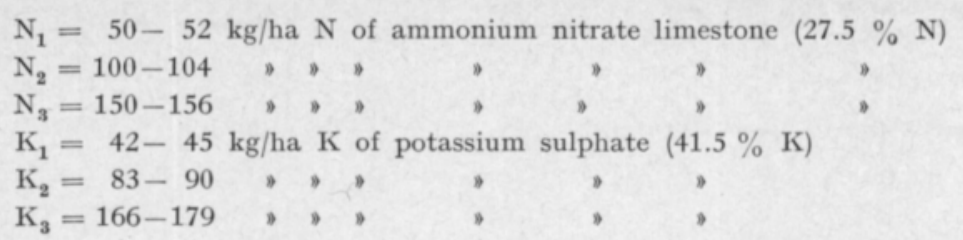

All the trial plots were supplied with base fertilizer to the extent of $174 \mathrm{~kg} / \mathrm{ha}$ $\mathrm{P}$ (in 1969) and $87 \mathrm{~kg} / \mathrm{ha} \mathrm{P}$ (in 1970-1971) in the form of superphosphate $(8.7 \% \mathrm{P})$. The fertilizers were mixed into the soil by harrowing.

Experiments were carried out at the experimental stations (trials 1-9), and in an abridged form on the fields of farmers (trials 10-14) using only two nitrogen rates, $\mathrm{N}_{1}$ and $\mathrm{N}_{3}$. The trials were of one-year duration. There were three replicates, and the size of the plots was $50 \mathrm{~m}^{2}$. In eleven of the trials the potato variety was Pito, and in the rest Vesijärvi, Nuutti, and Rekord. The trial plots were situated on sand and fine sand soils except one, which was on fine sand moraine soil. From the plots soil samples were taken before the fertilizers were spread and the soil was tested by using acid ammonium acetate (Vuorinen and Mäkití 1955, KuRKi et al. 1965) (Table 1).

The tuber yield, the tuber size distribution, the starch content, and the extent of disease affliction were determined. Also, by using sensory perception, the tubers were graded according to quality (scale $1-9$ ) based on: the mealiness, the flavor, and darkening before and after cooking. All of these observations were not made for all the tuber samples. The significance of the results was tested by means of variance, correlation, and regression analyses. The different growing conditions in different growing locations and in different years caused significant variation in all the properties studied. Since the interaction of nitrogen and potassium was not significant, the results have been presented as mean values for different levels of nitrogen and potassium.

Table 1. The site of the trials, the year, the type of soil, and the results of soil tests.

\begin{tabular}{|c|c|c|c|c|c|c|}
\hline \multirow{2}{*}{$\begin{array}{l}\text { Trial } \\
\text { No. }\end{array}$} & \multirow{2}{*}{ Year } & \multirow{2}{*}{$\mathrm{pH}_{\left(\mathrm{H}_{2} \mathrm{O}\right)}$} & \multicolumn{4}{|c|}{$\mathrm{mg} / \mathrm{l}$ of soil } \\
\hline & & & $\mathrm{Ca}$ & $\mathrm{P}$ & K & $\mathrm{Mg}$ \\
\hline 1 & 1969 & 5.8 & 1100 & 8.5 & 110 & 55 \\
\hline 2 & 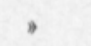 & 5.6 & 1325 & 19.0 & 230 & 115 \\
\hline 3 & , & 5.7 & 975 & 18.0 & 80 & 40 \\
\hline 4 & 1970 & 6.1 & 1580 & 12.1 & 256 & 108 \\
\hline 5 & 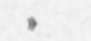 & 5.6 & 1325 & 19.0 & 230 & 115 \\
\hline 6 & 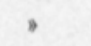 & 5.5 & 725 & 12.7 & 150 & 80 \\
\hline 7 & 1971 & 5.8 & 925 & 7.9 & 115 & . \\
\hline 8 & , & 6.6 & 1600 & 16.0 & 230 & 140 \\
\hline 9 & , & 5.4 & 625 & 12.1 & 140 & 57 \\
\hline 10 & , & 6.3 & 1000 & 5.5 & 160 & 38 \\
\hline 11 & , & 6.2 & 1390 & 12.5 & 325 & 270 \\
\hline 12 & , & 5.9 & 800 & 4.9 & 158 & 43 \\
\hline 13 & , & 5.6 & 850 & 41.2 & 103 & 85 \\
\hline 14 & , & 5.6 & 900 & 34.3 & 133 & 130 \\
\hline
\end{tabular}




\section{Results}

Increasing the rate of potassium fertilization did not cause a significant effect in a single trial, nor when the date were studied as a whole, even though the rate of potassium application in the tests varied within $42-179 \mathrm{~kg} / \mathrm{ha} \mathrm{K}$ (Table 2, Fig. 1). The amount of potassium in the soil varied in the trials within $80-325 \mathrm{mg} / 1$ of soil.

In the yields, obtained with the various rates of application of nitrogen, a significant difference was obtained at five trial plots $(3,4,9,10$ and 12), as well as when basing the calculation on all the data. The $\mathrm{pH}$ and the nutrient contents, as indicated by the soil test, did not affect the yield increase caused by nitrogen. On the basis of the obtained yield results the detrimental effect of an excessive nitrogen fertilization was evident. The calculations showed that the maximum yield was obtained with a nitrogen rate of $110 \mathrm{~kg} / \mathrm{ha}$, on the average.

The interaction of the nitrogen and the potassium fertilizations on the yield was significant only in trial 12, in which, when the smallest nitrogen rate was used, increasing the rate of potassium decreased the yield. When a more abundant nitrogen fertilization was used a big rate of potassium application turned out to be advantageous. The amount of potassium in the soil was in this trial $158 \mathrm{mg} / \mathrm{l}$ of soil. This is the same as the average potassium content in these trials.

The starch content $(\%)$ decreased, depending on the amount of nitrogen applied, on the average by 1 percent unit upon increasing the nitrogen fer-

Table 2. Tuber yield, $\mathrm{t} / \mathrm{ha}$.

\begin{tabular}{|c|c|c|c|c|c|c|c|c|c|c|c|}
\hline \multirow{2}{*}{$\begin{array}{c}\text { Trial } \\
\text { No. }\end{array}$} & \multicolumn{3}{|c|}{$\mathrm{N}_{1}$} & \multicolumn{3}{|c|}{$\mathrm{N}_{2}$} & \multicolumn{3}{|c|}{$\mathrm{N}_{3}$} & \multicolumn{2}{|c|}{ Significances } \\
\hline & $\mathrm{K}_{1}$ & $\mathrm{~K}_{2}$ & $\mathrm{~K}_{4}$ & $\mathrm{~K}_{1}$ & $\mathrm{~K}_{2}$ & $K_{4}$ & $\mathrm{~K}_{1}$ & $\mathrm{~K}_{2}$ & $\mathrm{~K}_{4}$ & $\mathrm{~N}$ & NK \\
\hline 1 & 29.6 & 29.5 & 30.6 & 29.3 & 29.4 & 31.6 & 29.9 & 29.0 & 29.2 & & \\
\hline 2 & 37.7 & 39.2 & 37.0 & 40.1 & 39.7 & 40.1 & 39.2 & 39.8 & 37.5 & & \\
\hline 3 & 13.7 & 13.6 & 14.1 & 16.6 & 17.1 & 17.0 & 18.0 & 18.5 & 17.8 & $* * *$ & \\
\hline 4 & 30.9 & 29.4 & 32.4 & 36.0 & 33.7 & 33.2 & 34.5 & 40.0 & 37.0 & $* * *$ & \\
\hline 5 & 33.2 & 32.7 & 33.0 & 33.9 & 32.0 & 34.1 & 32.5 & 31.9 & 32.8 & & \\
\hline 6 & 32.2 & 31.6 & 34.2 & 32.8 & 34.2 & 31.9 & 33.3 & 30.3 & 32.0 & & \\
\hline 7 & 32.0 & 33.2 & 33.4 & 33.2 & 32.7 & 32.6 & 30.4 & 29.6 & 32.1 & & \\
\hline 8 & 27.2 & 26.7 & 26.6 & 26.8 & 26.1 & 24.4 & 27.7 & 24.5 & 24.1 & & \\
\hline 9 & 26.4 & 28.3 & 28.3 & 27.8 & 31.2 & 32.4 & 28.8 & 28.1 & 28.3 & * & \\
\hline 10 & 29.4 & 29.8 & 29.3 & & & & 32.0 & 30.2 & 30.7 & $*$ & \\
\hline 11 & 38.3 & 35.1 & 35.2 & & & & 38.6 & 39.5 & 39.8 & & \\
\hline 12 & 32.7 & 32.6 & 28.7 & & & & 36.9 & 36.6 & 42.2 & $* * *$ & $*$ \\
\hline 13 & 36.6 & 40.0 & 35.2 & & & & 32.5 & 36.7 & 38.7 & & \\
\hline 14 & 27.3 & 30.1 & 29.1 & & & & 27.7 & 29.6 & 28.3 & & \\
\hline Average & & & & & & & & & & & \\
\hline$(1-14)$ & 30.5 & 30.8 & 30.5 & & & & 31.6 & 31.7 & 32.2 & * & \\
\hline Average & & & & & & & & & & & \\
\hline$(1-9)$ & 29.2 & 29.4 & 30.0 & 30.7 & 30.7 & 30.8 & 30.5 & 30.2 & 30.1 & * & \\
\hline
\end{tabular}




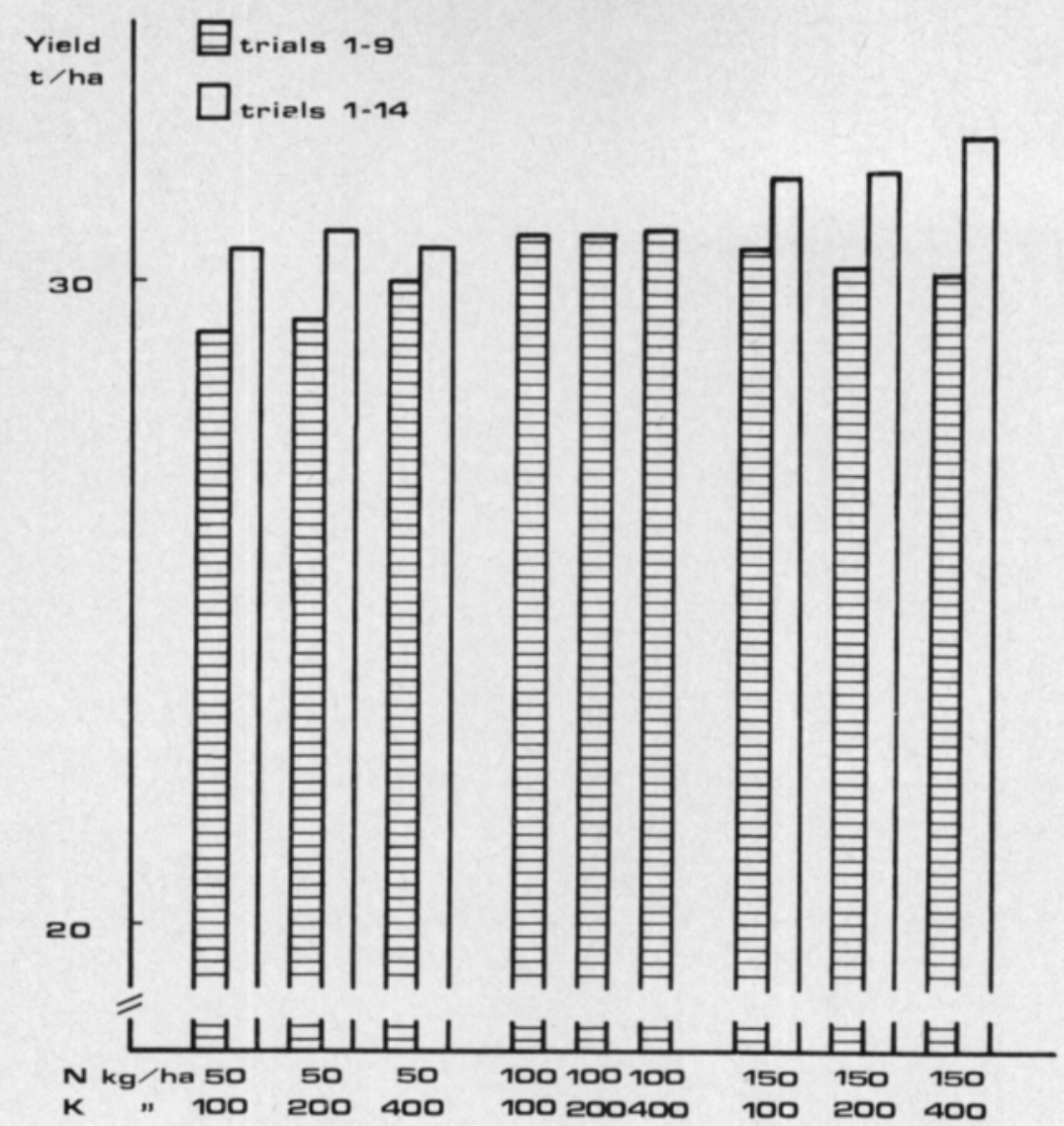

Fig. 1. The average tuber yields at the various levels of nitrogen and potassium fertilization.

tilization from 50 to $150 \mathrm{~kg} / \mathrm{ha}$. The effect of the potassium fertilization was not significant. With the maximum rate of potassium application a slightly lowered starch content was generally obtained, especially when an abundant nitrogen fertilization was used. The average starch contents $(\%)$ at the various nitrogen and potassium rates were the following ${ }^{1}$ ):

\begin{tabular}{llllll} 
& \multicolumn{2}{c}{ Trials } & \multicolumn{3}{c}{ Trials } \\
& $1-9$ & $1-14$ & & $1-9$ & $1-14$ \\
$\mathrm{~N}_{1}$ & $18.8^{\mathrm{a}}$ & $17.9^{\mathrm{b}}$ & $\mathrm{K}_{1}$ & $18.4^{\mathrm{a}}$ & $17.4^{\mathrm{a}}$ \\
$\mathrm{N}_{2}$ & $18.3^{\mathrm{b}}$ & & $\mathrm{K}_{2}$ & $18.3^{\mathrm{a}}$ & $17.5^{\mathrm{a}}$ \\
$\mathrm{N}_{3}$ & $17.9^{\mathrm{a}}$ & $16.8^{\mathrm{a}}$ & $\mathrm{K}_{4}$ & $18.2^{\mathrm{a}}$ & $17.1^{\mathrm{a}}$
\end{tabular}

The starch yield was at its minimum with the maximum nitrogen fertilization due to the decrease in the starch content. However, the differences in the average starch yields obtained with the various rates of nitrogen application were not significant.

Potassium had no effect' on the starch yield. The starch yield $(\mathrm{kg} / \mathrm{ha})$ was the following at the various levels of nitrogen and potassium fertilization:

1) The means having the same index letter do not differ significantly from each other. 


\begin{tabular}{cccccc} 
& \multicolumn{2}{c}{ Trials } & & \multicolumn{2}{c}{ Trials } \\
& $1-9$ & $1-14$ & & $1-9$ & $1-14$ \\
$\mathrm{~N}_{1}$ & $5596^{\mathrm{a}}$ & $5466^{\mathrm{a}}$ & $\mathrm{K}_{1}$ & $5578^{\mathrm{a}}$ & $5368^{\mathrm{a}}$ \\
$\mathrm{N}_{2}$ & $5647^{\mathrm{a}}$ & & $\mathrm{K}_{2}$ & $5547^{\mathrm{a}}$ & $5438^{\mathrm{a}}$ \\
$\mathrm{N}_{3}$ & $5433^{\mathrm{a}}$ & $5291^{\mathrm{a}}$ & $\mathrm{K}_{4}$ & $5551^{\mathrm{a}}$ & $5330^{\mathrm{a}}$
\end{tabular}

The tuber size distribution was only determined for six trials. For this classification 40 and $55 \mathrm{~mm}$ mesh screens were used. An increase in the rate of nitrogen fertilization increased the fraction of $55 \mathrm{~mm}$ (and bigger) tubers and decreased the fraction of small (below $40 \mathrm{~mm}$ ) tubers in the whole crop. The size distribution (\%) was, on the average, the following:

$\begin{array}{lccc} & \text { under } 40 \mathrm{~mm} & 40-55 \mathrm{~mm} & \text { over } 55 \mathrm{~mm} \\ \mathrm{~N}_{1} & 21.3^{\mathrm{b}} & 56.3^{\mathrm{a}} & 22.4^{\mathrm{a}} \\ \mathrm{N}_{2} & 17.3^{\mathrm{a}} & 56.3^{\mathrm{a}} & 26.4^{\mathrm{b}} \\ \mathrm{N}_{3} & 17.7^{\mathrm{a}} & 55.2^{\mathrm{a}} & 27.1^{\mathrm{b}} \\ \mathrm{K}_{1} & 18.8^{\mathrm{a}} & 56.5^{\mathrm{a}} & 24.7^{\mathrm{a}} \\ \mathrm{K}_{2} & 19.5^{\mathrm{a}} & 55.4^{\mathrm{a}} & 25.1^{\mathrm{a}} \\ \mathrm{K}_{4} & 17.9^{\mathrm{a}} & 55.9^{\mathrm{a}} & 26.2^{\mathrm{a}}\end{array}$

The tuber weight increased upon an increase in the rate of nitrogen fertilization. The slight negative effect obtained in connection with an increase in the potassium rate was not significant. The average weight (grams) at the various fertilization rates was:

\begin{tabular}{crcrrc}
\multicolumn{4}{c}{ Trials } & \multicolumn{3}{c}{ Trials } \\
\multicolumn{1}{c}{$1-9$} & $1-14$ & \multicolumn{3}{c}{$1-9$} & $1-14$ \\
$\mathrm{~N}_{1}$ & $74^{\mathrm{a}}$ & $74^{\mathrm{a}}$ & $\mathrm{K}_{1}$ & $78^{\mathrm{a}}$ & $75^{\mathrm{a}}$ \\
$\mathrm{N}_{2}$ & $78^{\mathrm{b}}$ & & $\mathrm{K}_{2}$ & $77^{\mathrm{a}}$ & $75^{\mathrm{a}}$ \\
$\mathrm{N}_{3}$ & $80^{\mathrm{b}}$ & $75^{\mathrm{a}}$ & $\mathrm{K}_{4}$ & $77^{\mathrm{a}}$ & $73^{\mathrm{b}}$
\end{tabular}

The mealiness was classified on a 1-9 scale, and the classification was based on four factors: disintegration, consistency, structure, and dryness. The quality of the trade potato is classified from 3 (not mealy, firm, hard, slightly humid) to 7 (mealy), and, as usable for mash potato, class 9 (very mealy, dry). The mealiness varied in the experiments within the range $3.5-9.0$, and was the following at the various nitrogen and potassium application rates:

\begin{tabular}{llclrc} 
& \multicolumn{2}{c}{ Trials } & \multicolumn{3}{c}{ Trials } \\
& $1-9$ & $1-14$ & & $1-9$ & $1-14$ \\
$\mathrm{~N}_{1}$ & $7.4^{\mathrm{b}}$ & $7.4^{\mathrm{b}}$ & $\mathrm{K}_{1}$ & $7.2^{\mathrm{a}}$ & $7.1^{\mathrm{a}}$ \\
$\mathrm{N}_{2}$ & $7.0^{\mathrm{ab}}$ & & $\mathrm{K}_{2}$ & $7.2^{\mathrm{a}}$ & $7.2^{\mathrm{a}}$ \\
$\mathrm{N}_{3}$ & $6.8^{\mathrm{a}}$ & $6.7^{\mathrm{a}}$ & $\mathrm{K}_{4}$ & $6.8^{\mathrm{a}}$ & $6.8^{\mathrm{a}}$
\end{tabular}

The smaller the rate of nitrogen application, the mealier the tubers.

The flavor was classified on a scale from unfit to eat, strongly off-flavor (1) to delicious, no off-flavor (9). The classification grade for fit to eat was 5 . The flavor classification grade varied in the tests within the range 4.5-9.0, and was, on the average, the following at the various nitrogen and potassium rates:

\begin{tabular}{llclcc} 
& \multicolumn{2}{c}{ Trials } & \multicolumn{3}{c}{ Trials } \\
& $1-9$ & $1-14$ & & $1-9$ & $1-14$ \\
$\mathrm{~N}_{1}$ & $7.6^{\mathrm{b}}$ & $7.8^{\mathrm{b}}$ & $\mathrm{K}_{1}$ & $7.5^{\mathrm{a}}$ & $7.5^{\mathrm{a}}$ \\
$\mathrm{N}_{2}$ & $7.5^{\mathrm{ab}}$ & & $\mathrm{K}_{2}$ & $7.4^{\mathrm{a}}$ & $7.5^{\mathrm{a}}$ \\
$\mathrm{N}_{3}$ & $7.1^{\mathrm{a}}$ & $7.3^{\mathrm{a}}$ & $\mathrm{K}_{4}$ & $7.3^{\mathrm{a}}$ & $7.6^{\mathrm{a}}$
\end{tabular}


Increasing the rate of application of nitrogen had, on the average, a slightly detrimental effect on the flavor. Increasing the rate of potassium fertilization did not have a uniform effect on the flavor.

The extent of after-cooking darkening was determined from peeled, cooked tubers after an interval of 24 hours. Grade 1 was given to the totally darkened, and grade 9 to the undarkened tubers. The grades from 5 (fairly much darkened, apparent change in color) to 9 are fit to eat. The fertilization did not have a significant effect on the after-cooking darkening, and the results were the following:

\begin{tabular}{crc} 
& \multicolumn{2}{c}{ Trials } \\
& $1-9$ & $1-14$ \\
$\mathrm{~N}_{1}$ & $7.0^{\mathrm{a}}$ & $6.4^{\mathrm{a}}$ \\
$\mathrm{N}_{2}$ & $6.7^{\mathrm{a}}$ & \\
$\mathrm{N}_{3}$ & $6.8^{\mathrm{a}}$ & $6.2^{\mathrm{a}}$
\end{tabular}

\begin{tabular}{ccc} 
& \multicolumn{2}{c}{ Trials } \\
& $1-9$ & $1-14$ \\
$\mathrm{~K}_{1}$ & $6.8^{\mathrm{a}}$ & $6.3^{\mathrm{a}}$ \\
$\mathrm{K}_{2}$ & $6.8^{\mathrm{a}}$ & $6.4^{\mathrm{a}}$ \\
$\mathrm{K}_{4}$ & $6.7^{\mathrm{a}}$ & $6.2^{\mathrm{a}}$
\end{tabular}

The discoloration of raw tubers was determined 24 hours after splitting the raw potato. The grades spanned the range from wholly blackened (1) to not at all blackened (9). As fit to eat were classified the not more than fairly much blackened, clearly color altered tubers (5). In the trials the discoloration of raw tubers varied within the range $2.0-7.6$. There was significantly less blackening, judging by all the tests, when $50 \mathrm{~kg}$ of nitrogen was used than when $150 \mathrm{~kg}$ was used. The discoloration of raw tubers was not significantly affected by the potassium rates. Only the difference in the discoloration obtained between the trial at the maximum nitrogen rate and the trial at the minimum nitrogen rate was notable. At the various fertilization rates discoloration was observed as follows:

\begin{tabular}{|c|c|c|c|c|}
\hline \multicolumn{2}{|c|}{ Trials } & & \multicolumn{2}{|c|}{ Trials } \\
\hline $1-9$ & $1-14$ & & $1-9$ & $1-14$ \\
\hline $5.0^{\mathrm{a}}$ & $5.1^{\mathrm{b}}$ & $\mathrm{K}_{1}$ & $4.7^{\mathrm{a}}$ & $4.8^{\mathrm{a}}$ \\
\hline $4.5^{\mathrm{a}}$ & & $\mathrm{K}_{2}$ & $4.7 \mathrm{a}$ & $4.9^{\mathrm{a}}$ \\
\hline $4.6^{\mathrm{a}}$ & $4.6^{\mathrm{a}}$ & $\mathrm{K}_{\mathrm{a}}$ & $4.7 \mathrm{a}$ & $4.8^{\mathrm{a}}$ \\
\hline
\end{tabular}

The trials revealed rather scanty disease affliction in the tubers. In some tuber samples there was a slight amount of black scurf, and only in a few trials was there scab infection to a somewhat greater extent. In 1971, when the season precending harvesting was rainier and colder than normally, there was silver scurf in the potatoes. In the above mentioned trials the test treatments had no effect on the extent of tuber disease affliction. ${ }^{1}$ )

\section{Discussion}

The recommendation for the use of a certain rate of fertilization depends on many factors. One of the factors that influence the effectiveness of the fertilization most strongly is the weather during the growing season. The significance of the weather as a factor influencing the potato yield depends, in part, on the soil. The results of the trials under consideration indicated great variations with respect to the various years as well as the various trial fields.

1) Primary results concerning the quality of tubers have been published in Finnish (TäHTINEN 1977). 
At planting time it is not possible to forecast the weather for the growing season. Thus, it is necessary to make the fertilization recommendation on the basis of average results obtained in field trials. However, it is possible to take into account in this connection the nutrient condition of the soil and other factors affecting the need for the plant nutrients, such as variety, preceding crop, soil, fertilizer application method, etc.

According to the results, nitrogen fertilization had a more marked effect than potassium fertilization on the tuber yield as well as on the quality of the tubers.

After the yield level variation among the various trial fields has been eliminated from the data, the coefficients in the equation (SEARLE 1971) $\mathrm{y}_{\mathrm{ij}}=\mu+\mathrm{a}_{\mathrm{i}}+\mathrm{bx}_{\mathrm{ij}}+\mathrm{cx}_{\mathrm{ij}}{ }^{2}+\mathrm{e}_{\mathrm{ij}}$, representing the dependence of the yield (y $\mathrm{kg} / \mathrm{ha})$ on the rate of nitrogen application $(\mathrm{x} \mathrm{kg} / \mathrm{ha})$, are: $\mathrm{b}=76.074$ and $\mathrm{c}=$ -0.343 . Thus the maximum yield would be obtained, on the average, at the nitrogen rate of $110 \mathrm{~kg} / \mathrm{ha} \mathrm{N}$.

On the basis of the price structure prevailing in Finland in 1976, $1 \mathrm{~kg}$ of $\mathrm{N}$, if used in the form of chlorine-free NPK compound fertilizer for potatoes $(\mathrm{N}: \mathrm{P}: \mathrm{K}=7: 11: 12)$, corresponds to a $1.52 \mathrm{~kg}$ yield of potatoes. Thus the economical optimum will be about $80 \mathrm{~kg}$ of $\mathrm{N}$, if only the tuber yield is taken into account. If also the detrimental effects of nitrogen on the quality (the starch content, the size distribution, the flavor, etc.) are taken into account, the recommendable nitrogen rate for starch and table potato will be, depending on the variety, the type of soil, and the cultivation conditions, even smaller that the above when broadcasting is used. In the investigations of VARIS (1970), the best economical return was achieved with a greater $(90-110 \mathrm{~kg} / \mathrm{ha}$ $\mathrm{N})$ nitrogen rate than that mentioned above. In the present trials the differences in the yields obtained as a function of the nitrogen rate were slight. This shows that the tuber yield is fairly insensitive to variations in the rate of nitrogen application on both sides of the calculated optimum. Due to the small number of trials carried out, their results can only be valid for circumstances similar to these trials.

Great differences can exist among the various varieties in their ability to utilize nutrients (e.g. Svensson et al. 1972). Especially the rate of nitrogen application should be designed to conform with the growth potential of the cultivated variety. With the late varieties an abundant growth of the haulm caused by nitrogen fertilization will lower the tuber yield. The early varieties which produce big tubers have the best ability to use nitrogen. The cultivated variety was in the eleven trials of this study the Finnish variety "Pito" (MANNER and Ravantti 1969). Thus, for earlier varieties more nitrogen may be used. Also, when producing seed potatoes, the optimum rate of nitrogen fertilization is greater than for table and starch potatoes (VARIS 1974). However, the differences between the various varieties manifest themselves most clearly when high rates of nitrogen fertilization are used (BAERUG and ENGE 1971, Svensson et al. 1972). Differences between the varieties have been observed to exist also with respect to the potassium yield. According to a Norwegian study, table potatoes benefited more from an abundant potassium fertilization than did industrial potatoes (EKEBERG and RøNSEN 1973). 
In the present study the preceding crop in seven trials was potato or a root crop, in four it was fallow, and in three the preceding crop was a grain crop. The trials revealed no significant effect of the preceding crops on the need for nitrogen. It has, however, been observed that the preceding crop has an effect on the nitrogen fertilization demand of potato (BAERUG and ENGE 1971, FURUNES 1975).

The method of fertilizer application can, especially in dry growing seasons, have an appreciable effect on the crop yield. In these trials the fertilizers were spread onto the surface and then mixed into the soil by harrowing. The optimum results are obtained, with placing or drilling fertilization, at a fertilization rate about a quarter smaller than with broadcasting (HøJMARK 1976). The fertilizer placement is more advantageous with a light fertilization than with a heavier one. Drilling or placing the fertilizers increases the proportion of large tubers in the crop (LARPES 1970, VARIS and LANNETTA 1974). However, the yield increase caused by fertilization depends strongly on the method of placing (LINNer 1972). The field trials concerned with the method of fertilizer application have generally been carried out using NPKcompound fertilizers. Placing the fertilizers has then also increased the starch content of the crop.

The quality of potato varies depending on the conditions of fertilization as well as, and often even more so, on the conditions of the trial locality. Often the type of utilization of the tubers, along with the intended yield, affects the fertilization recommendation. A nitrogen fertilization raised, in the field trials under consideration, the average weight of the tubers. Correspondingly, the proportion of bigger than $40 \mathrm{~mm}$ tubers in the crop increased. Thus, a nitrogen fertilization can decrease the yield of first class table potato, if the proportion of bigger than $70 \mathrm{~mm}$ tubers in the crop increases. In the present study this proportion has not been determined. According to VARIS (1973 a), a nitrogen fertilization increases not only the size of the tubers but also their number.

When trying to obtain a big starch yield, however, less nitrogen fertilizers should be used than when trying to reach a big tuber yield. The starch collects into the tuber at the end of the growing season. The temperature of this season is, therefore, important. A nitrogen fertilization, on the other hand, causes a postponement of the development of potato. From this follows that the starch content will be lowered as a result of the nitrogen fertilization. In the present study the starch content decreased by about 1 per cent unit per $100 \mathrm{~kg}$ of nitrogen. Therefore, $100 \mathrm{~kg} / \mathrm{ha} \mathrm{N}$ did not produce a significantly greater starch yield than did $50 \mathrm{~kg} / \mathrm{ha} \mathrm{N}$, regardless of the correspondingly greater tuber yield at the bigger nitrogen rate. The biggest nitrogen rate produced the smallest starch yield. The differences in the starch yield were not, however, significant. In almost all the studies carried out in this country (VARIs 1970, Ellala et al. 1971) the decreasing effect of nitrogen on the starch content has been noted. The mealiness of potato is also connected with its starch content. The greater the rate of nitrogen fertilization the lower the mealiness. At low mealiness an increase in the rate of nitrogen fertilization lowers the fraction of good table potato in the yield. 
In the present trials the potassium was given as the sulphate, which, according to many investigations, has proved to be a better potassium fertilizer for potato than potassium chloride (e.g. LäHDE 1935, Halin and Johansson 1973, НøJмARK 1977). An increase in the potassium rate from $42 \mathrm{~kg}$ to $179 \mathrm{~kg}$ did not significantly affect the yield in spite of the fact that the potassium content of the soil was in most trials rather low. In this respect the result departed from the experimental results obtained, among others, by VARIS (1972 a). In several investigations the effect of potassium on the yield has been quite small in comparison with that of nitrogen.

Further, potassium had no effect on the properties determining quality. VARIS (1972 b) has noted in his investigations, in which, in fact, the range in the rate of application of potassium $(0-332 \mathrm{~kg} / \mathrm{ha} \mathrm{K})$ was greater than in the present trials, that not only increasing the nitrogen rate, but also increasing the potassium rate, is detrimental to the flavor of potato. However, according to Ellala et al. (1971) potassium fertilization has no effect on the flavor if one compares potatoes of the same specific weight, i.e., potatoes belonging to the same starch content class.

It has been possible to avoid discoloration of raw and cooked potato caused by heavy nitrogen fertilization by increasing the rate of potassium fertilization (Ellala et al. 1971, VARIs 1972 b, BAERUG and ENGE 1974).

The trials were intended to help in investigating the relation between the increase in the yield and the nutrient content of the soil, i.e., to elucidate the possibility of using the results of soil tests for forecasting fertilization needs. In the present trials there was no correlation between the yield increase obtained with various nitrogen rates $(50-156 \mathrm{~kg} / \mathrm{ha} \mathrm{N})$ or various potassium rates $(42-179 \mathrm{~kg} / \mathrm{ha} \mathrm{K})$ and the results of the soil tests. The narrow range in the potassium fertilization rate and in the potassium content of the soil, as well as the small number of trials may, for their part, have been factors causing the poor correlation. In addition, the magnesium content of the soil was low at several trial sites and in a couple of trials (10 and 12) disproportionately low in comparison with the potassium content of the soil. VARIS (1973 b) and Halin and Johansson (1973) have noted a negative correlation between the yield increase due to potassium and the potassium content of the soil at potassium fertilization rate between 0 and $332 \mathrm{~kg} / \mathrm{ha} \mathrm{K}$.

\section{REFERENCES}

Anon. Kemira Oy. Lannoitteiden hinnasto. 7 p. Helsinki.

- 1977 b. Board of Agriculture. Statistical Office, Finland. Monthly review of agricultural statistics. 1977: $280-311$.

BaErug, R. \& Enge, R. 1971. Virkning av sterk nitrogengjødsling og omløpsform på avling og ulike kvalitetsegenskaper hos matpoteter. I. Virkninger på avling og naeringsopptak. Norges Landbr.høgsk. Meld. 50: 1-25.

- - \& ENGE, R. 1974. Influence of potassium supply and storage conditions on the discoloration of raw and cooked potato tubers of cv. Pimpernel. Potato Res. 17: 271282.

EKeberG, E. \& Rønsen, K. 1973. Virkningen av kaliumgodsel på 5 potetsorter i lågere deler av Hedmark og Oppland 1968-71. Forskn. For. Landbor. 24: 209-219. 
Ellala, A., Vanhanen, L. \& Kurkela, R. 1971. Typpi- ja kalilannoituksen vaikutus ruokaperunan laatuun. Abstract: The influence of nitrogen and potassium fertilizing on the specific gravity and cooking quality of potato varieties Bintje and Realta. J. Scient. Agric. Soc. Finl. 43, 2: 63-75.

Furunes, J. 1975. Gjøsling med nitrogen, fosfor og kalium til poteter i Trødndelag. Forskn. Fors. Landbr. 26: 203-218.

Halin, M. \& Johansson, O. 1973. Fosfor- och kaliumgödsling till matpotatis. Summary: Phosphours and potassium fertilization to food potatoes. Lantbr.högsk. Medd. A. 192: 1-47.

Нøлмакк, J. V. 1976. Placering og bredsåning af NPK-gødning til sildige kartofler. Abstract: Placement and broadcastning of NPK-fertilizer for late mature potatoes. Tidsskr.

Planteavl. 80: 211-220.

JoKINEN, R. 1977. Kalkituksen ja runsaan kaliumlannoituksen vaikutus magnesiumlannoituksella saatavaan tulokseen. Maanviljelyskemian ja -fysiikan laitos. Tiedote n:o 2: $1-29$.

Kurki, M., Lakanen, E., Mäkitie, O., Sillanpää, M. \& Vuorinen, J. 1965. Viljavuusanalyysien tulosten ilmoitustapa ja tulkinta. Summary: Interpretation of soil testing results. Ann. Agric. Fenn. 123: 223-232.

LARPes, G. 1970. Rivilannoitus lisää perunasatoja. Pellervo 71: 422-423.

LiNnÉR, H. 1972. Modellförsök med radgödsling till potatis. Svenska potatisodlares riksförbund, Potatis 1972: $38-39$.

LÄHDE, V. 1935. Perunan lannoituskokeiden tuloksia Maatalouskoelaitoksen kasvinviljelyosastolla vuosina 1931-34. Rep. State Agric. Res. 88: 1-8.

Manner, R. \& Ravantti, S. 1969. Pito-peruna. Summary: Pito potato. Ann. Agric. Fenn. 8: $214-227$.

SEARLE, S. R. 1971. Linear models. 532 p. New York.

Svensson, B., Carlsson, H., Westerling, E., Hagman, C.-G. \& Bodin, B. 1972. Matpotatis. Odling og hantering. Aktuellt från Lantbr. Högsk. 178: 1-34.

TÄHtınen, H. 1977. Perunan typpi- ja kaliumlannoitus. Maanviljelyskemian ja -fysiikan laitoksen tiedote n:o 5. 24 p.

VARIS, E. 1970. Variation in the quality of table potato and the factors influencing it in Finland. J. Scient. Agric. Soc. Finl. 118, 3: 1-99.

- 1972 a. The effects of increasing NPK rates on the yield and quality of the Pito potato. I. Tuber yield, starch content and starch yield. J. Scient. Agric. Soc. Finl. 128, 1: 1-20.

- 1972 b. The effects of increasing NPK rates on the yield and quality of the Pito potato. II. External and internal quality. J. Scient. Agric. Soc. Finl. 128, 2: 1-23.

- $-1972 \mathrm{c}$. The effect of magnesium and potassium on the cehmical composition and yield of the potato. J. Scient. Agric. Soc. Finl. 128, 3:1-13.

- 1972 d. Factors affecting the yield and quality of protein in the potato. J. Scient. Agric. Soc. Finl. 128, 4:1-13.

- 1973 a. NPK-lannoituksen vaikutus Pito-perunan satotekijöihin. Abstract: The effects of increased N, P, and $\mathrm{K}$ rates on yield factors of Pito potato. J. Scient. Agric. Soc. Finl. 45: 489-500.

— - 1973 b. Perunallekin tarkennettu lannoitus. Käytännön Maamies 1973, 12: $22-23$.

- - 1974. Kasvuolojen ja lannoituksen vaikutus siemenperunan sadontuottokykyyn ja sadon laatuun. Abstract: The effects of growing conditions and manuring on the yield capacity of seed potatoes and on the subsequent crop quality. J. Scient. Agric. Soc. Finl. 46: 63-79.

- - \& LANnetra, I. 1974. Lannoitustavan vaikutus perunasadon kehittymiseen ja sadon laatuun. Abstract: Effects of fertilization rate and application method on the yield development and quality of potatoes. J. Scient. Agric. Soc. Finl. 46: 328-340.

Vuorinen, J. \& Mäkitie, O. 1955. The method of soil testing in use in Finland. Agrogeol. Publ. 63: 1-44.

Ms received January 12, 1978. 


\section{Perunan typpi- ja kaliumlannoitus}

\section{HiLKKa TÄHTINEN}

Maatalouden tutkimuskeskus, Maanviljelyskemian ja -fysiikan laitos, 01300 Vantaa 30.

Maatalouden tutkimuskeskuksen maanviljelyskemian ja -fysiikan laitos sekä koeasemat ovat suorittaneet 14 perunan N- ja K-lannoituskoetta. Kokeet olivat 1-vuotisia monitekijäkokeita, jotka sijaitsivat karkeilla kivennäismailla. Perunalajike oli useimmissa kokeissa Pito. Typpilannoitus $(50-156 \mathrm{~kg} / \mathrm{ha} \mathrm{N})$ annettiin oulusalpietarina ja kalium $(42-179 \mathrm{~kg} / \mathrm{ha} \mathrm{K})$ kaliumsulfaattina.

Typpilannoituksen lisääminen vaikutti merkitsevästi sekä sadon suuruuteen että laatuun. Tulosten perusteella todettiin laskennollisesti, että näissä kokeissa suurin mukulasato saavutettiin typpimäärällä $110 \mathrm{~kg} / \mathrm{ha}$. Taloudellisesti edullisin typpilannoitemäärä vuoden 1976 hintojen mukaan laskien oli $80 \mathrm{~kg}$ typpeä hehtaarille, jos tarkastellaan vain sadon määrää.

Typpilannoitus heikensi sadon laatua. Mukuloiden paino ja koko suurenivat typpilannoituksella. Mitä suurempaa typpilannoitusta käytettiin, sitä alempi oli mukuloiden tärkkelyspitoisuus. Tämän vuoksi tärkkelyssato jäi pienimmäksi runsaimmalla typpilannoituksella, joskaan erot eri typpimäärien vaikutusten välillä eivät olleet merkitseviä.

Kaliumlannoituksella ei ollut merkitsevää vaikutusta sadon suuruuteen eikä laatuun. Yhdessä kokeessa typen ja kaliumin yhteisvaikutus sadon suuruuteen oli merkitsevä, jolloin kaliumlannoituksen lisääminen oli edullista suurta typpilannoitusta käytettäessä. Lannoitteilla saatu vaikutus ei näissä koeolosuhteissa riippunut koemaiden viljavuustutkimuksen tuloksista.

Suurin typpimäärä huononsi mukuloiden makua, alensi jauhoisuutta ja lisäsi hieman raakatummumista. Koekäsittelyillä ei ollut vaikutusta keitetyn perunan jälkitummumiseen.

Vain muutamissa kokeissa oli mukuloissa perunarupea ja harmaahilsettä. Näiden mukulatautien esiintymisrunsauteen ei koekäsittelyillä ollut vaikutusta. 